\title{
ACTIVE WAITING AS BUSINESS STRATEGY: LEARNING FROM THE SERENGETI PLAINS
}

\author{
C. W. Von Bergen \\ Southeastern Oklahoma State University • Durant, Oklahoma \\ Martin S. Bressler \\ Southeastern Oklahoma State University • Durant, Oklahoma
}

\section{ABSTRACT}

Fast decision making, a propensity for action, and getting things done appear to be highly valued by both practitioners and academics in the United States. Under such monikers as exhibiting initiative, being proactive, walking the talk, and taking charge, getting things done is widely lauded and promoted. As a result, most managers are content to deal with day-to-day operational activities that require immediate attention, daily routines, and superficial behaviors rather than addressing important issues requiring reflection, systematic planning, creative thinking - and above alltime. To address this often unproductive busyness the authors propose active waiting which involves the recognition that not all problems are open to a quick fix and that sometimes waiting can be a valuable option. However, waiting does not have to be passive. The authors recommend that managers act like the skilled, veteran lions of the Serengeti plains and adopt active waiting in order to be able to seize the opportune moment in pursuit of effective business strategy. This paper offers a sixstep process to help leaders integrate active waiting into their supervision style and concludes with recommendations for managers.

Keywords: Business strategy, active waiting, second-mover advantage

\section{INTRODUCTION}

"Every morning in Africa, a gazelle wakes up. It knows it must run faster than the fastest lion or it will be killed. Every morning a lion wakes up. It knows it must outrun the slowest gazelle or it will starve to death. It doesn't matter whether you are a lion or a gazelle. When the sun comes up, you better start running" (Friedman, 2005, p. 114).

The above quote by Thomas Friedman reminds us that organizations are competing for their very survival and that the quickest, swiftest, and fastest continue to live another day while those left behind become food for the lion. Fast action enables both people and organizations to survive and flourish. However, while running is im- 
portant for lions, lions also need to be cautious in doing so. Younger lions lacking in experience, will instinctively chase targets often resulting in failure. Successful hunters surprise their victims after carefully scanning the horizon and patiently waiting with focused attention for just the right circumstances before taking action (Stander \& Albon, 1993). The key to the lion's survival is not only size and strength, but also cleverness in knowing when and how to attack their prey. Even when hungry, lions will forego a meal rather than hazard a hasty and uncontrolled attack (Haas, 2013).

The Serengeti plains of Africa provide us with an important lesson regarding business strategy. That lesson features an overemphasis on quick decision making and speed of action that in many instances at the expense of reflective thinking, thoughtfulness, and resourcefulness demonstrated by the lions' successful hunting strategy. Both the academic and practitioner literature in the United States emphasize the importance of quick decision making and fast action.

\section{Taking Action-The Practitioner's Perspective}

The emphasis on swift action has become so entrenched in management thinking that FastCompany, and their magazine is now a popular read for many business managers. The bias for action has also been underscored by many practitioneroriented books. For example, Eccles and Nohria (1992), in their book Beyond the Hype wrote that "Management was, is, and always will be the same thing: the art of getting things done.... And to get things done, managers must act themselves and mobilise collective action on the part of others" (p. 32). Further, Kelley (1998) emphasized initiative along with other proactive behaviors as the explanation that distinguishes top performing employees from average employees in his book How to Be a Star at Work. In addition, Bruch and Ghoshal (2004) stated in their book A Bias for Action, that management is essentially the art of doing and getting things done.

Renowned management guru and former Chairman of General Electric Jack Welch, said that "An organization's ability to learn, and translate that leaping into action rapidly, is the greatest competitive advantage" (Welch, n. d.). We are reminded that relentless execution is central to achieving superior business performance (Bruch \& Ghoshal, 2010), and we generally respect individuals who make decisions quickly and even refer to them as "decisive" - a highly valued quality (Greenberg, 2011). In their book In Search of Excellence (1982) Peters and Waterman pointed to "a bias for action" (p. 119) as an important attribute of excellent companies that supports and strengthens all other qualities. Additionally, Peters and Waterman prescribed "Ready, Fire, Aim" (p. 119) as the means to build an action orientation. 
These books and others provide motivating accounts of organizational heroes who achieve significant success by emphasizing action and speed while at the same time implying that those slow to act are modern-day dinosaurs destined for extinction. The importance of action is even celebrated in motivational posters such as "The Essence of Survival" from Friedman's 2005 bestseller The World is Flat and his accompanying words in the introduction of this paper.

From another perspective, the term "analysis paralysis" or "paralysis of analysis" refers negatively to a situation where a person or an organization continues to rework or refine analyses, calculations, or computations, thus extending the decision making process and taking more time than reasonable and necessary, and in some instances with the result being no action taken (Langley, 1995). Because over the past decade the organizations' ability to gather, store, access, and analyze data has grown exponentially, too much analysis is becoming an increasing problem (Shah, Horne, \& Capellá, 2012).

\section{Taking Action-The Academic Perspective}

Additionally, the academic literature reports and promotes the importance of fast decision making and taking action. A great deal of research addresses proactive issues (Parker \& Collins, 2010), actively adjusting to new job conditions (Ashford \& Black, 1996), using initiative (Den Hartog \& Belschak, 2007), communication to positively change the organization (LePine \& Van Dyne, 1998), promoting critical issues to leaders (Dutton \& Ashford, 1993), taking charge to effect change (Morrison \& Phelps, 1999), self-initiated role expansions (Parker, Wall, \& Jackson, 1997), the need for employees to be self-starting (Campbell, 2000; Ibarra, 2003), and the importance of network building (Morrison, 2002).

From another perspective Keinan and Bereby-Meyer (2012) observed the danger in avoiding taking action rather than taking action in areas such as dodging cancer screenings (Howard \& Huang, 2012) or not saving for retirement (Kogut \& Dahan, 2012), as well as other researchers have investigated the dangers of inaction including the Status Quo Bias, which is the tendency for people to prefer the current situation rather than consider similar or possibly better options (Kahneman, Knetsch, \& Thaler, 1991). Despite different terminology and theoretical foundations, these concepts involve an action mindset or in other words, "making things happen."

Procrastinators are typically labeled lazy, indolent, and unambitious - pejorative words in achievement-oriented societies (Knaus, 1973). DeSimone (1993), however, reported that many pre-industrialized societies did not have words compa- 
rable to today's notion of procrastination. Similar words or constructs have existed throughout history, although with different, and usually less negative, connotations. The term procrastination comes directly from the Latin verb procrastinare, meaning quite literally, to put off or postpone until another day (DeSimone, 1993). This actually is a compilation of two words - pro, a common adverb implying forward motion, and crastinus, meaning "belonging to tomorrow." The combined word was used numerous times in Latin texts and seemed to reflect the notion that deferred judgment may be necessary and prudent, such as when it is best to wait the enemy out and demonstrate patience in military conflict (Ferrari et al., 1995). Furthermore, the Oxford English Dictionary (OED, 1989) lists the earliest known English usage of the word procrastination as occurring in 1548 in Edward Hall's Chronicle: The Union of Two Noble and Illustrious Families of Lancestre and Yorke. According to the OED, the word procrastination was in common usage by the early 1600 s and notes that the term was used several times in this work and apparently without disparaging connotations, reflecting more of the concept of "informed delay" or "wisely chosen restraint" popular in Roman accounts (Ferrari, 2001, p. 30).

The negative moral connotations of the term did not seem to emerge until the mid-18th century, at approximately the time of the Industrial Revolution. Perhaps to the ancients, procrastination involved a sophisticated, astute decision regarding when not to act. This paper examines such an interpretation as well as questioning the implicit expectation that managers must do everything quickly, must be permanently active, and must not hesitate to take immediate action. Active waiting as described in the successful lion hunts noted earlier in this paper is offered as an alternative approach.

\section{ACTIVE WAITING}

The nature of a manager's job typically leaves little room for reflection, resulting in supervisors who might ignore or postpone dealing with the organization's most crucial issues since such matters usually require a "big picture" perspectivewhich means reflection, systematic planning, or creative thinking, and - above alltime. Managers often spend much of their time addressing trivial operational issues that require their energy, time, and focus but are insignificant in the grand scheme of things. Daily routines, superficial behaviors, or poorly prioritized tasks act like leeches on managers' capacities - making unproductive busyness perhaps the most critical behavioral problem in companies (Bruch \& Ghoshal, 2010).

American fast-action culture calls for easy answers and quick solutions de- 
mand managers determine what is wrong and act quickly to resolve the situation. The abundance of technology and the "instant gratification" technological advancements typically bring (Samuelson, 1995) increases the need for quick solutions. Managers will often jump to a conclusion and then try to implement the solution they reached. This course of action causes managers to limit their search, not consider all alternatives, and pay enough attention to people who would be affected by the decision, not realizing that decisions often fail because of these reasons (Nutt, 1999). Fast action is most often favored, even in situations where there is no real time pressure. There seems to be a strong inclination to move forward and a fear of being seen as an indecisive manager. Even when managers know that making decisions this way is foolhardy, the pressure for hasty solutions often wins out (Nutt, 1999).

\section{The Virtue of Patience}

Organizations tend to be dominated by cultures of frenzy and unreflected activity (Gosling \& Mintzberg, 2003). Energized action is necessary, but that does not mean being hyperactive or continuously implementing change. Taking time for reflection, seriously reviewing and questioning projects are neither the usual practice nor well received in many organizations. Rarely do firms question such values. That is what makes The International Federation of Red Cross and Red Crescent Societies, headquartered in Geneva, Switzerland so unique. Executives there worried that it was drifting too far toward a fast-action culture. It realized that it must act quickly in responding to disasters everywhere - earthquakes, wars, floods and famines — but it also saw the need to engage in the slower, more delicate task of building a capacity for action that was careful, thoughtful, and tailored to local conditions and needs. What was needed was an approach where reflective thinking meets practical doing (Gosling \& Mintzberg, 2003).

Active waiting, or what the Center for Advanced Health refers to as "Watchful Waiting", is a common practice in the health care profession. Doctors believe that for certain medical conditions the preferred strategy is to delay treatment while monitoring progress of the illness. In fact, in many instances, such as aching muscles or a child's ear infection, the illness may be minor and go away on its' own. Using the "watchful waiting" approach, doctors can often better determine the best approach to treating the illness (http:www.cfah.org).

Active waiting is recommended to encourage the necessary management reflection,. It is a process in which individuals intentionally hold back from impetuously diving into making irreversible commitments of resources (Minniti, 2006). 
This, however, takes patience. It is often hard for individuals to believe that they will get more done by starting out slowly, patiently, planfully (i.e., by waiting around), but the patience of active waiting is essential for slowing and preparing the mind, which otherwise races on to the next crisis. Therefore, "active waiting is less a matter of time management than of emotional management" (Boice, 2000, p. 108).

\section{Leveraging The Second-Mover Advantage}

Many business strategists advocate the value of "first-mover advantage", being first to market with an innovative new product or technology. Other strategy analysts support another school of thought that proposes "second-mover advantage" in which organizations and companies that are followers benefit by learning from first-movers mistakes. These "second movers" in many cases are then able to surpass those companies that rushed to be first in the market. Henricks (2009) cites several companies that benefitted from second-mover advantage. For example, Voodoo Tiki Tequila, a high-end tequila liquor challenged the category market leader, Patron Spirits Company. Patron's strategy was based on educating and convincing consumers to switch from drinking vodka to instead drinking tequila.

Second-mover Tiki Voodoo Tequila did not have to spend the time, effort, and money educating consumers as Patron had already taken on that task. Instead, Tiki instead chose to make significant improvements to packaging. While Patron uses a traditional style Mexican packaging, Tiki uses bottles made from hand-blown glass with a tiki inside the bottle. In addition, each bottle is numbered, giving the impression of a limited series collection. Consumers now willingly pay more for a perceived premium, high-end Tequila liquor product.

Henricks (2009) points to other examples of successful second-movers including Southwest Airlines, which learned from earlier entrants in the economy segment of the airline industry. In addition, Google gained considerable knowledge from the experience of previous search engine companies (e.g., WebCrawler and Lycos). Although Nokia and Ericsson were the early entrants in the cell phone industry, today, companies like Samsung and Apple tower over the market. Active waiting allows the second-mover to take advantage of the market leader's mistakes or lack of follow-through. In some instances, the market leader might lack intellectual property protection or channels of distribution. In other examples, high costs associated with research and development or market introduction could leave the company in a financially weakened position. In addition, the first-mover might have introduced their product before all the product errors were identified and corrected. 
Other examples can also be found where second-mover companies benefitted by active waiting: Target stores learned from WalMart and AMD computer acquired important information from observing Intel. The real test however is profitability. Rasmusen and Yoon (2012) found that when second-movers possess better business or product knowledge, the company can employ second-mover advantage resulting in greater profits.

What about the strategic importance of speed? Gamble, Thompson, and Peteraf (2013) reported that mobile phone usage around the world did not immediately take off. In fact, it took ten years for the industry to grow from 10 million users to 100 million users worldwide! Similarly, it took nearly ten years for broadband home usage to reach 100 million users around the globe. Gamble et al. (2013) also remind us that the market penetration curve for many business opportunities is much longer than many businesses estimate. Many additional companies could likely benefit from an active waiting strategy and take better advantage of business opportunities within the market penetration curve.

\section{PUTTING ACTIVE WAITING INTO PRACTICE}

The authors propose a six-step process to implement an active waiting strategy. This approach calls for managers to be doubtful, generate alternatives, assess the alternatives, be flexible, implement slowly, and then take action. This six-step procedure is illustrated in Figure 1 and is discussed below.

\section{Figure 1}

\section{The Six-Step Process of Active Waiting}

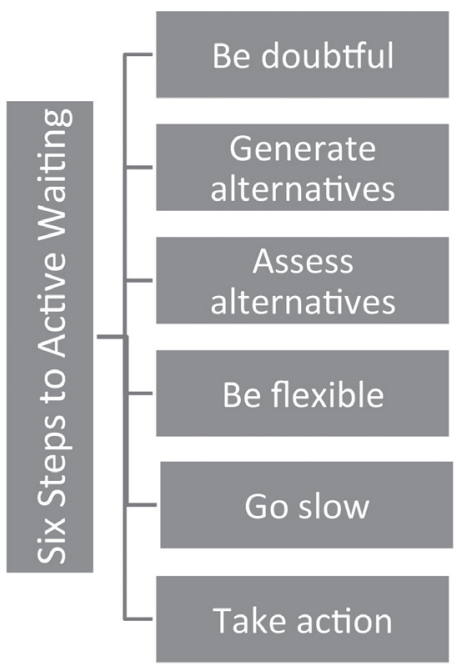




\section{Be Doubtful}

People and organizations both appear to be culturally eager to praise the power of conviction. Self-confident persons demonstrate sureness in their ability to make decisions, organize and execute action plans, perform new tasks, and offer opinions (Mayo, Kakarika, Pastor, \& Brutus, 2012). Self-confident leaders are also more likely to be assertive and decisive, which gains others' confidence in decisions which is crucial for their effective implementation. Moreover, Kirkpatrick and Locke (1991) identified self-confidence as one of six key leadership traits. If leaders are not sure of what decision to make, or express a high degree of doubt, then followers are less likely to trust those leaders and be committed to their vision.

Such confidence, in fact overconfidence, seems to be central to human nature (Kahneman, 2011). Individuals are often confident even when they are wrong, and an objective observer is more likely to detect their errors than the person who is wrong. People often have excessive confidence in what they believe they know, and an apparent inability to acknowledge the full extent of their ignorance and the uncertainty of the world they live in. They are prone to overestimate how much they understand about the world and their high subjective confidence is not to be trusted as an indicator of accuracy. Individuals also tend to exaggerate their ability to forecast the future, which fosters optimistic overconfidence (Kahneman, 2011).

Nevertheless, some degree of uncertainty may be useful. Bandura and Locke (2003) reported "In preparing for challenging endeavors, some self-doubt about one's performance efficacy provides incentives to acquire the knowledge and skills needed to master the challenges" (p. 96) and Chamorro-Premuzic (2012) indicated that being somewhat unsure may be helpful and serve as a catalyst for beneficial change. Woodman, Akehurst, Hardy, and Beattie (2010) also found that a decrease in self-confidence resulted in significant improvement in performance from practice to competition in a sports-related activity. Gladwell (2013) indicated that "[D]oubt was creative because it allowed for alternative ways to see the world, and seeing alternatives could steer people out of intractable circles and self-feeding despondency. Doubt, in fact, could motivate: freedom from ideological constraints opened up political strategies, and accepting the limits of what one could know liberated agents from their dependence on the belief that one had to know everything before acting, that conviction was a precondition for action." Doubt may help prevent what Barker (1993) describes as "paradigm paralysis" when it is assumed there is only one way to do something. This condition actually can prevent managers from exploring and considering other options. 


\section{Generate Alternatives}

The second step in the process involves developing alternate courses of action in response to an opportunity or threat. Management experts often cite the failure to consider alternatives as a key reason why managers sometimes make poor decisions (Bazerman \& Moore, 2008). Almost every discussion of effective decision making calls for developing multiple options. The rejected possibilities are not wasted, however, as they assist in confirming the value of a preferred course of action and frequently offers the means to improve it. Different choices allow managers in decision-making roles to combine the best features of various options to make a superior one, and to make a comparison with a preferred action to demonstrate its merits. Nutt (1999), however, reported that managers produced several courses of action in less than 20 percent of their decisions. When multiple options were developed, success rates jumped from 56 percent to 70 percent. Multiple ideas provide another way to increase one's chance of success but developing several possibilities is time consuming and to save time, the practice is often ignored.

Moreover, some managers are used to seeing the world from a single perspective due to their "managerial mind-set" and find it difficult to view problems from a fresh perspective. According to best-selling management author Peter Senge (2006), humans are trapped within our personal mental models of the world - that is, our ideas about what is important and how the world works. Generating creative alternatives to solve problems and take advantage of opportunities may require that we abandon our existing mind-sets and develop new ones-something that usually is difficult to do.

Managers today are encouraged to set aside their traditional paradigms of management decision making and generate creative alternatives. This new approach is reflected in the interest and growth in the work of authors such as Senge (2006) and de Bono (1968), who have popularized management techniques for stimulating problem solving and creative thinking. More recently Gladwell (2013) noted that creativity develops from embracing chaos and releasing control. Gladwell (2013) also noted that famed economist Albert Hirschman even criticized organizations like the World Bank for trying to remove obstacles and secure economic and infrastructural stability in developing countries. For Hirschman, obstacles cause frustration and anxiety, which in turn spur motivation. This chaotic unpredictability serves as the motor of creative energy — getting the rug pulled out from under us knocks us into a free fall that builds more momentum than standing securely on our feet. 


\section{Assess Alternatives}

Once managers have developed a set of alternatives, they must evaluate the advantages and disadvantages of each alternative (Russo \& Schoemaker, 1992). The key to a good assessment of the alternatives is to define the opportunity or threat exactly and then specify the criteria that should influence the selection of alternatives for responding to the problem or opportunity. One reason for bad decisions is that managers often fail to specify the criteria that are important in reaching a decision (Bazerman \& Moore, 2008). In general, successful managers use four criteria to evaluate the pros and cons of alternative courses of action (Jones \& George, 2011). Often times a manager must consider these four criteria simultaneously:

1. Legality: Managers must ensure that a possible course of action will not violate any domestic or international laws or government regulations.

2. Ethicalness: Managers must ensure that a possible course of action is ethical and will not unnecessarily harm any stakeholder group. Many decisions managers make may help some organizational stakeholders and harm others. When examining alternative courses of action, managers need to be clear about the potential effects of their decisions.

3. Economic feasibility: Managers must decide whether the alternatives are economically feasible-that is, whether they can be accomplished given the organization's performance goals. Typically managers perform a cost-benefit analysis of the various alternatives to determine which one will have the best net financial payoff.

4. Practicality: Managers must decide whether they have the capabilities and resources required to implement the alternative, and they must be sure the alternative will not threaten the attainment of other organizational goals. At first glance an alternative might seem economically superior to other alternatives; but if managers realize it is likely to threaten other important projects, they might decide it is not practical after all.

Some of the worst managerial decisions can be traced to poor assessment of the alternatives, such as the decision to launch the Challenger space shuttle. In that particular case, the desire of NASA and Morton Thiokol managers to demonstrate to the public the success of the U.S. space program in order to ensure future funding (economic feasibility) conflicted with the need to ensure the safety of the astronauts (ethicalness). Managers deemed the economic criterion more important and decided to launch the space shuttle even though there were unanswered questions about 
safety. Tragically, some of the same decision-making problems that resulted in the Challenger tragedy led to the demise of the Columbia space shuttle 17 years later, killing all seven astronauts on board (Berger, 2004). In both the Challenger and the Columbia disasters, safety questions were raised before the shuttles were launched; safety concerns took second place to budgets, economic feasibility, and schedules; top decision makers seemed to ignore or downplay the inputs of those with relevant technical expertise; and speaking up was discouraged (Glanz \& Schwartz, 2003). Rather than making safety a top priority, decision makers seemed overly concerned with keeping on schedule and within budget (Wald \& Schwartz, 2003).

\section{Be Flexible}

Centuries ago playwright and keen observer of human behavior William Shakespeare noted in The Merchant of Venice (1596) that "Thus hath the candle singed the moth" (Act 2 Scene 9) meaning that just as a moth is attracted to a flame that leads it to make a fatal mistake, so too are people irresistibly and dangerously tempted by situations that often lead to disaster. Similarly, in business a firm's steadfast commitment to a long-term view of what it should be doing and where it should be going, often touted as a powerful tool for improving corporate performance, can be problematic when such attraction leads to tunnel vision, a narrow concentration, and missing the big picture. For example, Sull (2004) details how Microsoft's fixation on mission statements related to PCs blinded them to opportunities and threats presented by the explosive growth of the Internet. Organizations must be careful to avoid such a "moth-to-candle syndrome" that can lead to its demise.

Rather than getting too focused on clear, long-term visions that can distract firms from emerging situations in the present, companies may want to consider softening such single-mindedness. Indeed, Sull (2005) tells leaders to "avoid marching headlong toward a well-defined future and instead articulate a fuzzy vision. ... A fuzzy vision works because it provides a general direction and sets aspirations without prematurely locking the company into a specific course of action" (p. 124). Such a vision contributes to a company's situational awareness - the ability to identify, process, and comprehend the critical elements of information about what is happening around it (United States Coast Guard, n. d.) - and can act as a corrective measure when organizations fixate on and become preoccupied with one aspiration often losing the ability to detect other important environmental information. Fuzzy visions can motivate employers to explicitly consider alternatives and options because the flexible perspective inherent in such mission statements can promote 
greater functional dissent and other forms of constructive conflict. Such flexibility is particularly important in rapidly changing environments, including emerging markets, technology intensive industries where change is often revolutionary rather than evolutionary, and fields where different industries are converging (e.g., information technology and entertainment).

\section{Implement Slowly}

The fifth step calls for measured, deliberate action. There is a saying in martial arts: you have to go slow to go fast. The idea is that individuals have to be relaxed and calm to move as quickly as they are capable of doing. Famous movie character, Ferris Bueller, voiced a similar theme when he said, "Life moves pretty fast. If you don't stop and look around once in a while, you could miss it" (Hughes, 1987).

More formally, Nobel Laureate Daniel Kahneman (2011) summarized the research literature on decision-making and problem solving and described mental life by the metaphor of two agents, called System 1 and System 2, which respectively produce fast and slow thinking. System 1 is generally automatic, affective, and heuristic-based, and relies on mental "shortcuts." It quickly proposes intuitive answers to problems as they arise. System 2, which corresponds closely with controlled processes, is slow, effortful, conscious, rule-based, and also can be employed to monitor the quality of the answer provided by System 1. If System 2 is convinced that our intuition is wrong, then it is capable of correcting or overriding the automatic judgments. System 2 takes over when things get difficult. Each system impacts the other because individuals have only so much attentional focus. If System 2 is engaged then System 1 may be negatively impacted. Intense focusing on a task can make people miss stimuli that normally attract attention.

System 1 thinking can also negatively impact System 2 thinking. In a business context Bruch and Ghoshal (2002) noted that frequently there is an astonishing amount of fast-moving activity in organizations that allows almost no time for reflection. Such unproductive busyness characteristic of System 1 thinking, and what Bruch and Ghoshal (2002) call "active nonaction," can be a hazard for managers and organizations since fully $90 \%$ of managers squander their time in all sorts of ineffective activities. What is needed is more System 2 thinking or what Bruch and Ghoshal (2002) refer to as concentrated attention - the ability to zero in on a goal and see the task through to completion which seem to define what they call purposeful managers. 
Such attention requires that purposeful managers choose not to respond immediately to every issue that comes their way or get sidetracked from their goals by distractions like email, meeting, setbacks, and unforeseen demands. Such System 2 thinking involves carefully weighing options before selecting a course of action. Moreover, because purposeful managers commit only one or two key projects, they can devote their full attention to the projects they believe in. Purposeful managers manage time carefully and some refuse to respond to phone calls or visitors outside certain periods of the day. Other such managers build "think time" into their schedules. One executive, Bruch and Ghoshal (2002) observed, frequently arrived at the office at 6:00 a.m. to think about issues before his colleagues showed up. This executive said, "In the busiest times, I slow (italics ours) down and take time off to reflect on what I actually want to achieve and sort what's important from irrelevant noise. Then I focus on doing what is most important" (Bruch \& Ghoshal, 2002, p. 68). Sometimes it is important to slow down and let an individual's System 2 take control, which is often associated with the subjective experience of agency, choice, and concentration. This involves active waiting. While the One Minute Manager (Blanchard \& Johnson, 1981) focused on quick action was a best seller some years ago, more and more discussion is today being focused on reflection and moving forward slowly (Honoré, 2004).

\section{Take Action}

The final step in the Six-step Strategy is to take action. This final step calls for applying the selected alternative and carrying out the decision. In taking action it may be fitting to consider various mental shortcuts that frequently sabotage managerial judgment and action. Hammond, Keeney, and Raiffa $(1998,1999)$ and Kahneman, Slovic, and Tversky (1982) have identified several key psychological traps that managers should be alert to and compensate for them when taking action.

An example of this would be the status quo bias - the tendency to stick to the current state. By being aware of the role that this bias plays in their own lives, individuals can take actions to reduce the influence of this bias in their decision making. To avoid this error managers should 1) ask if the status quo really serves their objectives, 2) ask if they would choose the status quo if it were not the status quo, and 3) downplay the effort or cost of switching from the status quo.

Like college students who mistakenly think that in a multiple-choice test, they should always stick with their first answer, rather than changing it (Benjamin, Cavell, \& Shallenberger, 1984), managers likewise often misguidedly stay with 
those options that first come to mind. They often fail even to think through the possible implications of information that would be harder to get.

To minimize the distortion caused by variations in "recallability," managers must take a very disciplined approach to making forecasts and judging probabilities and should 1) carefully examine all assumptions to ensure they are not unduly influenced by their memory and improperly give more weight to recent events, 2) get actual statistics whenever possible, and avoid being guided by impressions and dramatic events, and 3) try and recall instances of events that are not so memorable.

\section{SUMMARY AND CONCLUSION}

This paper focuses on the potential benefits of waiting strategically. To some degree this is in response to what the authors consider as an overemphasis on swift action, execution, and doing. While the "Ready, Fire, Aim" concept is about velocity and the profound benefits of moving from ideas into action-from thinking into doing - at the fastest possible speed, it is essential to realize that such an approach may do more harm than good since such a strategy may cause individuals to completely miss the target if activities are undertaken with reckless abandon and bolting into action before due diligence is exercised. Managers are encouraged to heed the words of noted financier, Warren Buffet (n. d.), who said "I insist on a lot of time being spent, almost every day, to just sit and think. That is very uncommon in American business. I read and think. So I do more reading and thinking, and make less impulse decisions than most people in business."

We offer active waiting as an alternative to the cultural and business demands for quick action. Today's fast-paced modern life, in many ways, has encouraged people to demand things immediately and to be impatient. People eat fast food, use high speed Internet, and command that their emails be answered within an hour. Active waiting, on the other hand, allows managers time for additional study, research and testing, consulting advisors, and thoughtful deliberation-in a word patience. Although some situations require a rapid response, emergencies for example, most day-to-day decisions managers make in the course of their duties allow more time to pause and consider possible courses of action.

Patience is not only a virtue, but can also be considered essential to sound management. The authors find numerous examples of the importance of patience (active waiting) in business, perhaps none more significant than a study by Baumann (2010) that found a firm can improve performance through moderate patience, allowing for some additional exploration of other possibilities. 
Rasmusen and Yoon (2012), Henricks (2009), and Birger (2006) support the advantages of active waiting. Companies ranging from Southwest Airlines to Lowe's home improvement stores benefited from being second-movers in their respective industries, resulting in better market positions and stronger financial performance. A famous quote by Sun Tzu in The Art of War (goodreads.com) states "if you wait patiently by the river, the body of your enemy will float by".

Like the lion waiting for the perfect time to strike its prey, smart managers and organizations need to take the time to thoroughly evaluate their environment, resisting the urge to act too quickly. As the authors present in this paper, many types of organizations find active waiting the best approach in their industry. The question then, is when will your company management adopt an active waiting strategy?

\section{REFERENCES}

Amsel, A. (1992). Frustration theory: Many years later. Psychological Bulletin, 112, 396-399.

Ashford, S. J., \& Black, J. S. (1996). Proactivity during organizational entry: The role of desire for control. Journal of Applied Psychology, 81, 199-214.

Bandura, A., \& Locke, E. A. (2003). Negative self-efficacy and goal effects revisited. Journal of Applied Psychology, 88(1), 87-99.

Barker, J. (1993). Paradigms: The business of discovering the future. New York: Harper Business.

Baumann, O. (2010). Search, failure, and the value of moderate patience. Retrieved at http://www.sbr-online.de/pdfarchive/einzelne_pdf/sbr_2010_july_234-259.pdf

Barratt, E. S., \& Patton, J. H. (1983). Impulsivity: Cognitive, behavioral, and psychophysiological correlates. In M. Zuckerman (Ed.), Biological bases of sensation seeking, impulsivity, and anxiety (pp. 77-116). Hillside, NJ: Lawrence Erlbaum Associates.

Bazerman, M. H., \& Moore, D. A. (2008). Judgment in managerial decision making (7th ed.).New York: Wiley.

Benjamin, L. T., Cavell, T. A., \& Shallenberger, W. R. (1984). Teaching of Psychology, 11(3), 133-141.

Berger, B. (2004, January 26). NASA: One Year after Columbia-Bush's New Vision Changes Agency's Course Midstream, Space News Business Report, Retrieved at http://www. space.com/spacenews/businessmonday_040126.html

Birger, J. (2006). Second-mover advantage. Fortune, 153(5), 20-21. 
Blanchard, K., \& Johnson, S. (1981). The one minute manager. New York: The William Morrow Company, Inc.

Boice, R. (2000). Advice for new faculty members. Needham Heights, MA: Allyn and Bacon.

Briñoll, P., Petty, R. E., \& Tormala, Z. L. (2006). The malleable meaning of subjective ease. Psychological Science, 17(3), 200-206.

Bruch, H., \& Ghoshal, S. (2002). Beware the busy manager. Harvard Business Review, 80(2), 63-69.

Bruch, H., \& Ghoshal, S. (2004). A bias for action: How effective managers harness their willpower, achieve results, and stop wasting time. Boston: Harvard Business School Press.

Bruch, H., \& Ghoshal, S. (2010). Think again: Management is the art of doing and getting done. Business Strategy Review, 21(2), 70-75.

Buffet, W. (n. d.). Warren Buffet Quotes. Retrieved at http:/www.goodreads.com/ author/quotes/756.Warren_Buffett

Campbell, D. J. (2000). The proactive employee: Managing workplace initiative. Academy of Management Executive, 14, 52-66.

Center for Advanced Health "What is Watchful Waiting?" Retrived at http://www. cfah.org/prepared-patient/make-good-treatment-decisions/

Chabris, C. F., \& Simons, D. J. (2009). The invisible gorilla: How our intuitions deceive us. New York: Crown Publishing.

Chamorro-Premuzic, T. (2012). Less-Confident People Are More Successful. Retrieved from http://blogs.hbr.org/2012/07/less-confident-people-are-more-su/

Den Hartog, D. N., \& Belschak, F. D. (2007). Commitment, affect and initiative at work. Journal of Occupational and Organizational Psychology, 80, 601-622.

de Bono, E. (1968). Lateral thinking. London: Penguin.

DeSimone, P. (1993). Linguistic assumptions in scientific language. Contemporary Psychodynamics: Theory, Research \& Application, 1, 8-17.

Dutton, J. E., \& Ashford, S. J. (1993). Selling issues to top management. Academy of Management Review, 18, 397-428.

Eccles, R. G., \& Nohria, N. (1992). Beyond the hype. Boston: Harvard Business School Press.

Ferrari, J. R. (2001). Getting things done on time: Conquering procrastination. In C. R. Snyder, Coping with stress: Effective people and processes (pp. 30-46). New York: Oxford University Press.

Ferrari, J. R., Johnson, J. L., \& McCown, W. G. (1995). Procrastination and task avoidance: Theory, research, and treatment. New York: Plenum Press. 
Freud, S. (1959). Collected papers, vol. 4. New York: Basic Books.

Friedman, T. L. (2005). The world is flat. New York: Farrar, Straus and Giroux.

Gamble, J., Thompson, A., \& Peteraf, M. (2013). Essentials of strategic management, the quest for competitive advantage (3rd ed.). New York: Irwin/McGraw-Hill.

Gladwell, M. (2013). The Gift of Doubt: Albert O. Hirschman and the Power of Failure. The New Yorker. Retrieved at http:/www.newyorker.com/arts/critics/ books/2013/06/24/130 624crbo_books_gladwell?currentPage=all

Glanz, J., \& Schwartz, J. (2003, September 26). Dogged engineer's effort to assess shuttle damage. The New York Times, p. A1.

Gollwitzer, P. M. (1996). The volitional benefits of planning. In P. M. Gollwitzer \& J. A. Bargh (Eds.), The psychology of action: Linking cognition and motivation to behavior (pp. 287-312). New York: Guilford.

Gosling, J., \& Mintzberg, H. (2003, November). The five minds of a manager. Harvard Business Review, 1-9.

Greenberg, J. (2011). Behavior in organizations (10th ed.). Upper Saddle River, NJ: PrenticeHall.

Haas, R. B. (2013). Masters of their universe: Business (and life) secrets taught by four-legged professors. Minneapolis, MN: Langdon Street Press.

Hammond, J. S., Keeney, R. L., \& Raiffa, H. (1998). The hidden traps in decision making. Harvard Business Review, 76(5), 47-48, 50.

Hammond, J. S., Keeney, R. L., \& Raiffa, H. (1999). Smart choices: A practical guide to making better decisions. Boston: Harvard Business Press.

Henricks, M. (2009, June). When second really is the best. Entrepreneur, 71-77.

Honoré, C. (2004). In praise of slow: How a worldwide movement is challenging the cult of speed. New York: HarperCollins Publishers.

Howard, D. H., \& Huang, Y. (2012). Serious health events and discontinuation of routine cancer screening. Medical Decision Making, 32, 627-635.

Hughes, J. (Director) (1987). Ferris Bueller's Day Off (movie). Paramount Pictures. Ibarra, H. (2003). Working identity: Unconventional strategies for reinventing your career. Cambridge, MA: Harvard Business School Press.

Jones, G. R., \& George, J. M. (2011). Contemporary management (Seventh ed.). New York: McGraw-Hill/Irwin.

Kahneman, D. P. (2011). Thinking, fast and slow. New York: Farrar, Straus, and Giroux. Kahneman, D. P., Knetsch, J. L., \& Thaler, R. H. (1991). Anomalies: The endowment effect, loss aversion, and status quo bias. The Journal of Economic Perspectives

Kahneman, D. P. Slovic, P., \& Tversky, A. (Eds.). (1982). Judgment under uncertainty: Heuristics and biases. New York: Cambridge University Press. 
Keinan, R., \& Bereby-Meyer, Y. (2012). "Leaving it to chance"-Passive risk taking in everyday life. Judgment and Decision Making, 7(6), 705-715.

Kelley, R. E. (1998). How to be a star at work: 9 breakthrough strategies you need to succeed. New York: Times Books.

Kirkpatrick, S. A., \& Locke, E. A. (1991). Leadership: Do traits matter? Academy of Management Executive, 5(2), 48-60.

Klein, G. (2007). Performing a project premortem. Harvard Business Review, 85(9), 18-19.

Knaus, W. (1973). Overcoming procrastination. Rational Living, 8, 2-7.

Kogut, T., \& Dahan, M. (2012). Do you look forward to retirement? Motivational biases in pension decisions. Judgment and Decision Making, 7, 282-291.

Langer, E. J. (1989). Mindfulness. New York: Perscus Books.

Langley, A. (1995). Between "paralysis by analysis" and "extinction by instinct." Sloan Management Review, 36(3), 63-76.

Lawson, R. (1965). Frustration: The development of a scientific concept. New York: Macmillan.

LePine, J. A., \& Van Dyne, L. (1998). Predicting voice behavior in work groups. Journal of Applied Psychology, 83, 853-868.

Loewenstein, G., \& Elster, J. (1992). Choice over time. New York: Sage.

Marrow, A. J., Bowers, D. F., \& Seashore, S. E. (1967). Management by participation. New York: Harper and Row.

Mayo, M., Kakarika, A. M., Pastor, J. C., \& Brutus, S. (2012). Aligning or inflating your leadership self-image? A longitudinal study of responses to peer feedback in MBA teams. Academy of Management Learning \& Education, 11(4), 631-652).

Minniti, M. (2006). Entrepreneurship. Westport, CN: Greenwood Publishing Group. Mischel, W. (1974). Processes in delay gratification. In L. Berkowitz (Ed.), Advances in experimental social psychology, vol. 7 (pp. 249-292). New York: Academic Press.

Morrison, E. W. (2002). Newcomers' relationships: The role of social networks during socialization. Academy of Management Journal, 45, 1149-1160.

Morrison, E. W., \& Phelps, C. C. (1999). Taking charge at work: Extrarole efforts to initiate workplace change. Academy of Management Journal, 42, 403-419.

Nutt, P. C. (1999). Surprising but true: Half the decisions in organizations fail. Academy of Management Executive, 13 (4), 75-90.

Oxford English Dictionary (2nd ed.). (1989). J. Simpson \& E. Weiner (Eds.). Oxford: Oxford University Press. 
Parker, S. K., \& Collins, C. G. (2010). Taking stock: Integrating and differentiating multiple proactive behaviors. Journal of Management, 36(3), 633-662.

Parker, S. K., Wall, T. D., \& Jackson, P. R. (1997). "That's not my job”: Developing flexible employee work orientations. Academy of Management Journal, 40, 899-929.

Peters, T. J., \& Waterman, R. H. J. (1982). In search of excellence: Lessons from America's best-run companies. New York: HarperTrade.

Rasmusen, E., \& Yoon, Y. (2012). First versus second mover advantage with information asymmetry about the profitability of new markets. Journal of Industrial Economics, 60(3), 374-405.

Read, J. D. (1995). The availability heuristic in person identification: The sometimes misleading consequences of enhanced contextual information. Applied Cognitive Psychology, 9(2), 91-121.

Rogers, W. (n. d.). Will Rogers Legacy: Remembering That Old Cowboy. Retrieved at http://www.parks.ca.gov/?page_id=23998

Russo, J. E., \& Schoemaker, P. J. H. (1992). Decision traps: Ten barriers to brilliant decision-making and how to overcome them.

Samuelson, R. J. (1995). The good life and its discontents: The American dream in the age of entitlement, 1945-1995. New York: Times Books.

Senge, P. M. (2006). The fifth discipline: The art \& practice of the learning organization. New York: Currency.

Shah, S., Horne, A., \& Capellá, J. (2012). Good data won’t guarantee good decisions. Harvard Business Review, 90(4), 23-25.

Shakespeare, W. (1596). The Merchant of Venice. Retrieved from http://www.opensource shakespeare.org/views/plays/playmenu.php?WorkID=merchantvenice

Stander, P. E., \& Albon, S. D. (1993). Hunting success of lions in a semi-arid environment. Symposia of the Zoological Society of London, 65, 127-143.

Sull, D. N. (2004). Look Out for the Tunnel Vision Trap. Retrieved from http://www.ft.com/cms/s/2/e0bcb1ac-e576-11d8-bfd2-00000e2511c8. html\#axzz2hthBw1xb

Sull, D. N. (2005). Strategy as active waiting. Harvard Business Review, 83(9), 120-129.

Sun Tzu. (n. d.). Sun Tzu Quotes. Retrieved at https://www.goodreads.com/ quotes/803224-if-you-wait-patiently-by-the-river-the-body-of

United States Coast Guard. (n. d.). Situational Awareness. Retrieved from http://www.uscg.mil/auxiliary/training/tct/chap5.pdf

Vanderbilt, T. (n. d.). Tom Vanderbilt Reviews The Invisible Gorilla. Retrieved at http://www.amazon.com/The-Invisible-Gorilla-Intuitions-Deceive/dp/0307459667 
Wald, M. L., \& Schwartz, J. (2003, August 28). NASA chief promises a shift in attitude. The New York Times, p. A23.

Welch, J. (n. d.). Retrieved from http://www.brainyquote.com/quotes/quotes/j/jackwelch 173305.html

Woodman, T., Akehurst, S., Hardy, L., \& Beattie, S. (2010). Self-confidence and performance: A little self-doubt helps. Psychology of Sport and Exercise, 11(6), 467-470.

\section{BRIEF BIOGRAPHICAL SKETCH OF AUTHORS}

C.W. Von Bergen is Professor of Management and the John Massey Endowed Chair in Management at Southeastern Oklahoma State University. Dr. Von Bergen has authored more than 100 articles for a wide variety of academic journals, focusing on the fields of human resources, employee relations, and organizational behavior issues.

Martin S. Bressler is Professor of Management \& Marketing and the John Massey Endowed Chair in Entrepreneurship at Southeastern Oklahoma State University. Dr. Bressler is a Fulbright Scholar and served as Resource Panel Expert to the 1995 White House Conference on Small Business. Dr. Bressler has authored many articles, focusing primarily on small business and entrepreneurship. 